\title{
The HMG-CoA Reductase Inhibitor Activities of Soy Protein Hydrolysates from Papain Hydrolysis
}

\author{
Sandra Hermanto ${ }^{*}$, Aldi Octavio' ${ }^{1}$ Azrifitria², Susi Kusumaningrum ${ }^{3}$ \\ 'Chemistry Study Program, Faculty of Science and Technology, UIN Syarif Hidayatulah Jakarta Indonesia \\ ${ }^{2}$ Pharmacy Study Program, Faculty of Health Sciences UIN Syarif Hidayatulah Jakarta Indonesia \\ ${ }^{3}$ Center for Pharmaceutical and Medical Technology BPPT Serpong, Tangerang Selatan Indonesia
}

*Corresponding author email: hermantokimia@uinjkt.ac.id

Received November 06, 2020; Accepted May 02, 2021 ; Available online July 20, 2021

\begin{abstract}
The search for an HMG-CoA reductase inhibitor agent as a safe and inexpensive alternative treatment for hypercholesterolemia has been carried out using soy protein hydrolysates as one of the bioactive peptide sources. This study was conducted to explore the potency of soy protein hydrolysates as an anti hypercholesterolemia agent by an in vitro assay, through the inhibition capacity of the HMG-CoA (3-hydroxy-3-methyl glutaryl-coenzyme A) reductase enzyme as a key component of cholesterol biosynthesis. Sample preparation started with soy protein isolation through acid precipitation and separated by centrifugation. The samples were analyzed the proximate content and hydrolyzed by papain enzyme at concentration $0.2 \%(\mathrm{w} / \mathrm{v})$, for $0-6$ hours and at 37,50 , and $55{ }^{\circ} \mathrm{C}$. The protein hydrolysates were subsequently evaluated for hydrolysis degree $(\% \mathrm{DH})$, hydrolysates profile with SDS-PAGE (Sodium Dodecyl Sulphate Polyacrylamide Gel Electrophoresis), and anti-cholesterol assay through HMG-CoA reductase inhibition tests. The sample with the highest inhibition activity was fractionated using gel filtration chromatography (Sephadex G-10) and the molecular weight of fractions was characterized by LCMS QTOF (Liquid Chromatography-Mass Spectrometry Quadrupole Time-of-Flight) for molecular weight determination. The results indicated the optimum hydrolysis conditions of soy protein isolates were obtained at 3 hours incubation, at $50{ }^{\circ} \mathrm{C}$ with $\mathrm{DH} 33.39 \%$ and the inhibition value was $95.65 \%$ (protein concentration $39.21 \mu \mathrm{g} / \mathrm{mL}$ ). LCMS data showed the molecular weight of fractionated peptides were 1514 and $2029 \mathrm{Da}$. We assumed that both peptides have the same affinity as previous peptides in inhibiting HMG-CoA reductase.
\end{abstract}

Keywords:, HMG-CoA reductase, hypercholesterolemia, papain hydrolysate, soy protein

\section{INTRODUCTION}

The presence of high-level cholesterol in the blood is a trigger for clogged arteries (atherosclerosis) and is further implicated in cardiovascular or coronary heart disease. This condition is a global threat and the number one cause of death worldwide. The report from American Heart Association (AHA) in 2017 shows over 17.8 million people die of heart and blood vessel disease, which is $21.1 \%$ higher than the data collected ten years ago (Virani et al., 2020). Meanwhile, a reduction in the consumption of fatty foods, performing physical exercises, combined with proper medication helps prevent and treat hypercholesterolemia. Moreover, there is a lack of substantive data to prove the direct relationship between high cholesterol levels and death. This disorder often results in atherosclerosis, stroke, and coronary heart disease (Csonka, Sárközy, Pipicz, Dux \& Csont, 2016)

According to previous studies, cardiovascular risks, including coronary heart disease and stroke are increased by hypercholesterolemia (Ramdath Padhi, Sarfaraz, Renwick, \& Duncan 2017); (Otvos et al., 2006). Furthermore, with regards to age distribution, cardiovascular is mostly diagnosed in people between $65-74$ (3.6\%) followed by 75 and above (3.2\%), 55-64 (2.1\%), and lastly $35-44$ years old (1.3\%), while according to economic status, this disease is common among the lower (2.1\%) and middle-income class (1.6\%) (Trialists, 2005).

Moreover, modern drugs, including lovastatin, pravastatin, gemfibrozil, fenofibrate are used to lower triglyceride and cholesterol levels (Hoie, 2010). However, people prefer to use statins, resulting from the capacity to quickly lower cholesterol levels. According to Hippisley-Cox, \& Coupland (2010), therapeutic applications in certain conditions trigger some side effects especially kidney failure, moderate/severe myopathy, cataracts, and liver dysfunction. The recommended dose in hypercholesterolemic patients is between 10 to 40 $\mathrm{mg} /$ day, and long-term usage has been implicated in myopathy, kidney failure, and liver damage (Lyons, \& Harbinson, 2009), while excess dose and certain conditions increase the risk of developing type 2 diabetes (Huupponen, \& Viikari, 2013). Previous studies have shown various herbs or food plants 
capable of reducing cholesterol levels with very minimal side effects.

Currently, there is less exploration of anticholesterol sources from natural food plants, where soybeans as one of the few potential resources. The research conducted a few decades ago identified beans as a plant-based food product with various antioxidants (Agyei, 2015) antimicrobial (Vasconcellos, Woiciechowski, Soccol, Mantovani, \& Soccol 2014), and antihypertensive potentials (Shimakage, Shinbo \& Yamada, 2012). Meanwhile, several types are also known to possess natural antioxidant-producing agents rich in phenolic compounds (Scalbert, Johnson, \& Saltmarsh, 2005). Also, supplements manufactured from soy grains help to lower cholesterol levels and soy protein can diminish heart disease risks by reducing blood cholesterol or low-density lipoprotein (LDL) levels (Ramdath et al., 2017). The soybean peptides LPYP, IAVPGEVA, and IAVPTGVA have been reported to effectively activate LDLR-SREBP 2 pathway and increase uptake of LDL in the blood, therefore inhibiting HMG-CoA reductase activity in HepG2 cells (Lammi, Zanoni, \& Arnoldi 2015). Furthermore, consuming diets low in saturated fat and cholesterol, including $25 \mathrm{~g}$ of soy protein per day is estimated to reduce the risk of heart disease. Dietary upregulation of LDL-R transcription by soybean may be consequent to an enhanced catabolism or a reduced synthesis of intracellular cholesterol. Soy peptides can effectively stimulate LDL-R transcription in the human liver cell line and reduce blood cholesterol level (Cho, Juillerat, \& Lee 2008)

The consumption of soy-based products has significantly reduced blood lipid content based on the composition. These include the protein isolates rich in isoflavones, soy fiber, cotyledons, and phospholipids (Anderson, \& Hoie, 2005). However, the reduction mechanism resulting from the presence of soy protein remains unclear, hence the need for further investigation. The use of supplements manufactured from soy has produced substantial efficacy and tolerability. Besides, many of these products currently in the market are claimed to lower cholesterol levels, although there is less valid scientific data to support this claim. This study was conducted to explore the potency of soy protein hydrolysates as an anti hypercholesterolemia agent by an in vitro assay, through the inhibition capacity of the HMG-CoA reductase enzyme as a key component of cholesterol biosynthesis.

Hydrolysis was performed using an enzyme: substrate ratio of $0.2 \%(\mathrm{w} / \mathrm{v})$ with variations in incubation times of $0,1,2,3,4,5$, and 6 hours at 37, 50, and $55{ }^{\circ} \mathrm{C}$ (Mutamimah, Ibrahim, \& Trilaksani 2018). The optimum treatment condition was determined based on dissolved protein content, degree of hydrolysis value, and anti-cholesterol activity. These were evaluated through an in vitro approach, using the enzyme HMG-CoA reductase. This is an important factor in determining cholesterol biosynthesis, especially for the formation of mevalonic acid from HMG-CoA, and also reduces blood cholesterol levels (Lyons \& Harbinson, 2009); (Rinto, Putri, \& Waktu, 2019). Furthermore, pravastatin was used as a positive control for HMGCoA reductase inhibitors, which played a key role in suppressing cholesterol synthesis (Murphy, Deplazes, Cranfield, \& Garcia, 2020). Consequently, the products' potentials with bioactive peptides from enzymatic hydrolysis are determined and expected to be applied as an alternative, cheaper, and safer anticholesterol agent.

\section{EXPERIMENTAL SECTION \\ Raw Materials and Chemicals}

The samples used in the study were obtained from supermarkets in the South Jakarta area. BSA (bovine serum albumin) (Sigma Aldrich), hydrochloric acids, PBS (phosphate-buffered saline), trichloro acetic acid (TCA), sodium dodecyl sulfate (SDS), Lowry I and Lowry II solutions, HMG-CoA reductase (SigmaAldrich), HMG-CoA, NADPH, pravastatin (Sigma Aldrich), acrylamide solutions (30\% T; $2.67 \mathrm{C}$ ) (BioRad) bis-acrylamide, resolving buffer (Tris- $\mathrm{HCl} 1.5 \mathrm{M}$ $\mathrm{pH} 8.8$ Bio-Rad); stacking buffer (Tris- $\mathrm{HCl} 0.5 \mathrm{M} \mathrm{pH}$ 6.8 Bio-Rad); ammonium peroxide disulfate (APS) $10 \% ; \mathrm{N}, \mathrm{N}, \mathrm{N}$ '-tetramethylethylenediamine (TEMED) (Sigma Aldrich); running buffer Sigma; Coomassie blue R-250 staining solution (Bio-Rad), phosphate buffer solution, methanol $(\mathrm{MeOH})$ and acetonitrile (ACN) grade liquid chromatography-mass spectrometry (LC-MS) from Sigma-Aldrich. Formic acid (FA) was obtained from Grüssing (Filsum, Germany), Sephadex G-10; Medium Cas No.905068-4 (Sigma-Aldrich).

\section{Sample Preparation}

These legumes of soybeans were cleaned and blended in cold water, then precipitated with $1 \mathrm{M}$ hydrochloric acid to obtain the hydroxylates. The mixture was further centrifuged at a speed of 12000 rpm for 15 minutes to produce protein precipitates. Therefore, dialysis was performed for 24 hours, before freeze-drying, and storage at $4{ }^{\circ} \mathrm{C}$.

\section{Proximate Analysis}

The proximate content of soy protein isolates was analyzed the crude protein, crude fat, moisture, and ash contents (AOAC International, 2016).

\section{Measurement of Protein Content}

The measurement of protein precipitate levels was conducted with the Bradford method using BSA solution as a standard ( $\mathrm{He}$ et al., 2015). This sample solution vortexed as the Bradford reagent was added and incubated at room temperature for 10 minutes. Furthermore, blue color with a $595 \mathrm{~nm}$ wavelength was produced, and the protein content was consequently extrapolated from the standard curve 
using the formula: $y=a x+b$ where: $y=$ absorbance, $x=$ concentration.

\section{Hydrolysis of Soy Protein Isolates}

The papain enzyme was used in the enzymatic hydrolysis of soy protein isolates. This was performed using a $7.5 \mathrm{pH}$ phosphate buffer at $0.1 \mathrm{M}$ concentration, as well as temperatures of 37,45 , and $50{ }^{\circ} \mathrm{C}$. The ratio of substrate used was $0.2 \%$ $(w / v)$ with an incubation time of $0-6$ hours (Mutamimah et al., 2018b). Furthermore, $5 \mathrm{~mL}$ of the mixture was obtained at intervals of $0,1,2,3,4,5$, and 6 hours during this process, then the degree of hydrolysis was measured. Subsequently, each hydrolysate mixture and the enzyme were inactivated by adding $0.5 \mathrm{M}$ Tris- $\mathrm{HCl}$ with $\mathrm{pH} 8$ and heated at $80{ }^{\circ} \mathrm{C}$ for 5 minutes.

\section{Determination of Hydrolysis Degree}

The degree of hydrolysis was determined using the SN-TCA method (Hoyle \& Merritt, 1994). Approximately $5 \mathrm{~mL}$ of protein hydrolysate was added with $20 \mathrm{~mL}$ TCA $10 \%(\mathrm{w} / \mathrm{v})$. This mixture was then allowed to settle for 30 minutes and centrifuged at a speed of $12000 \mathrm{rpm}$ for 15 minutes. The supernatant protein content was determined with the Bradford method, and consequently calculated with the following formula:

$$
\mathrm{N} \mathrm{HCl}=\frac{\text { TCA dissolved protein } 10 \%}{\text { the total protein sample }} \times 100 \%
$$

Anticholesterol Activity Assay (Liang et al., 2015) Reagent Preparation

The reagent used in this test contained an enzyme solution of HMG-CoA reductase dissolved in $550 \mu \mathrm{L}$ buffer. This substrate along with $\mathrm{NADPH}$ was dissolved in $1.3 \mathrm{~mL}$ and $440 \mu \mathrm{L} \mathrm{dH}_{2} \mathrm{O}$, respectively. Subsequently, all diluted reagents and a $10 \mathrm{mM}$ pravastatin inhibitor were stored at $-20{ }^{\circ} \mathrm{C}$ and room temperature respectively, before use.

Sample Preparation and Measurement of Inhibition \%

The protein hydrolysate sample was prepared and filtered using a $0.45 \mu \mathrm{m}$ membrane. Therefore, the filtrate was used as an inhibitor in the HMG-CoA reductase inhibition test with the help of an assay kit, where pravastatin was utilized as a positive control.
The \% measurement was performed at an ELISA reader wavelength of $340 \mathrm{~nm}$. Subsequently, reagents were added according to the details in Table 1.

Approximately $200 \mu \mathrm{L}$ of each mixture was read at a wavelength $(340 \mathrm{~nm})$ every minute for 10 minutes. The enzyme activity was then calculated using the equation:

$$
\begin{aligned}
& \text { Unit/mg } \mathrm{P}=\frac{(\Delta A 340 / \text { minsample }-\Delta A 340 / \text { minblank }) \times T V}{12.44 \times V \times 0.6 \times \mathrm{LP}} \\
& \text { Description: }
\end{aligned}
$$

12.44 = it needs $2 \mathrm{NADPH}$ during the reaction. (the coefficient for NADPH at $340 \mathrm{~nm}$ is $6.22 / \mathrm{mM} . \mathrm{cm}$ )

$\mathrm{TV}=$ Total reaction volume $(1 \mathrm{~mL})$

$\mathrm{V}=$ Volume of enzymes used

$0.6=$ Enzyme concentration in $\mathrm{mg}$-protein $(\mathrm{mgP}) / \mathrm{mL}$

$\mathrm{LP}=$ Ligh path $(1 \mathrm{~cm}$ for cuvettes and $0.55 \mathrm{~cm}$ for plate)

Furthermore, \% inhibition was calculated using the equation: $\%$ Inhibition =

Enzyme activity (non inhibitor)-Enzyme activity (pravastatin/sample)

$$
\text { Enzyme activity (non inhibitor) }
$$

$\times 100 \%$

\section{Analysis of SDS-PAGE Protein Hydrolysate}

The protein profile for soybean hydrolysates was determined using the SDS-PAGE method with a 7.5$17.5 \%$ resolving and $4 \%$ stacking gel solution in a buffer of 1.5 M Tris $\mathrm{HCl}$ at $\mathrm{pH} 8.45$ (Laemmli, 1970). These samples were denatured with a buffer, including $1 \%$ Coomassie brilliant blue, 25\% glycerol, 6. $8 \mathrm{pH}$ Tris- $\mathrm{HCl} 1 \mathrm{M}, 20 \% \mathrm{SDS}$, and boiled at $90{ }^{\circ} \mathrm{C}$ for 2 minutes where the ratio with protein was $1: 1$. The electrophoresis device was prepared using a resolving and stacking solution with a concentration of $1.5 \mathrm{M}$ and $0.5 \mathrm{M}$ at $\mathrm{pH} 8.8$ and 6.8 , respectively. The resulting sample was termed Tris- $\mathrm{HCl}$. Subsequently, $1.5 \%$ bisacrylamide and $48 \%$ acrylamide were added, and the electrophoresis process commenced for 55 minutes at a voltage of 150 volts with a Biorad protein marker, where the range of 7.7-204.0 kDa was compared. Also, 0.1\% (w / v) dye solvent was used for protein staining and

\begin{tabular}{|c|c|c|c|c|c|c|}
\hline Mixture & buffer $(\mu \mathrm{L})$ & $\begin{array}{l}\text { pravastatin } \\
(\mu \mathrm{L})\end{array}$ & $\begin{array}{c}\text { NADPH } \\
(\mu \mathrm{L})\end{array}$ & $\begin{array}{l}\text { HMG- } \\
\text { CoA }(\mu \mathrm{L})\end{array}$ & $\begin{array}{c}\text { HMGR } \\
(\mu \mathrm{L})\end{array}$ & $\begin{array}{l}\text { Hydrolysate } \\
(\mu \mathrm{L})\end{array}$ \\
\hline Blank & 184 & - & 4 & 12 & - & - \\
\hline $\begin{array}{c}\text { Negative } \\
\text { control }\end{array}$ & 182 & - & 4 & 12 & 2 & - \\
\hline $\begin{array}{l}\text { Positive } \\
\text { control }\end{array}$ & 181 & 1 & 4 & 12 & 2 & - \\
\hline Sample & 172 & - & 4 & 12 & 2 & 10 \\
\hline
\end{tabular}
the process yield was washed using $7.5 \%$ acetic acid and $40 \%$ methanol solvent.

Table 1. Addition of anti-cholesterol activity test reagents 
Table 2. Proximate content of soybean protein isolates

\begin{tabular}{lc}
\hline Proximate composition & Soy protein isolate (\%) \\
\hline Crude protein content & $36.59 \pm 0.01$ \\
Crude fat content & $10.24 \pm 0.26$ \\
Moisture content & $8.22 \pm 0.06$ \\
Ash content & $4.26 \pm 0.08$ \\
\hline
\end{tabular}

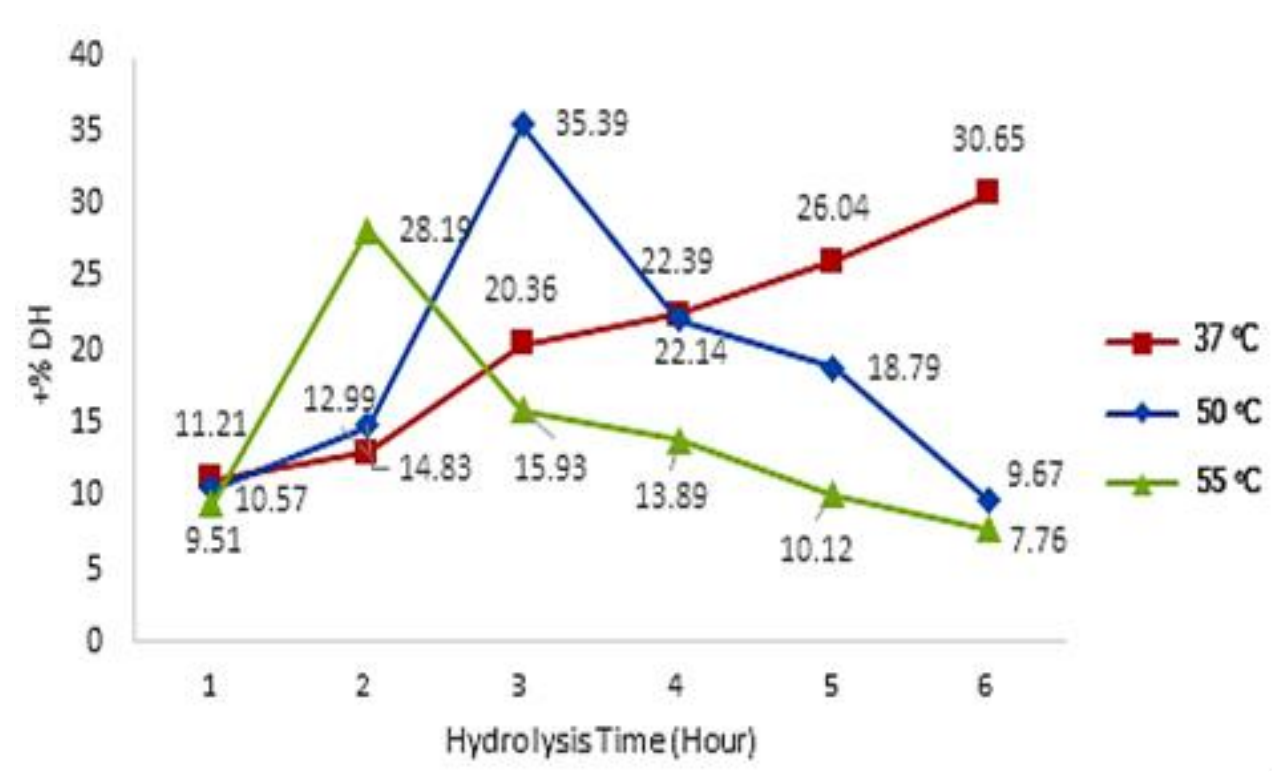

Figure 1. Soy protein isolate hydrolysis degree value at 37,50 , and $55^{\circ} \mathrm{C}$ hydrolysis temperatures

\section{Separation and Purification of Anti-Cholesterol Peptides from Hydrolysates}

The soybean protein hydrolysate with the highest anti-cholesterol activity value of $15 \mathrm{~mL}$ was concentrated by freeze-drying. This was consequently fractionated using a G-10 Sephadex column to separate the peptide portion below $3 \mathrm{kDa}$. The molecular weight was then analyzed using an LCMS/MS QTOF Mass Analyzer (Li, Li, Chang, \& Guo 2008)

\section{Peptide Identification using LCMS QTOF Mass Analyzer}

A total of $5 \mu \mathrm{L}$ purified peptides were obtained and filtered using a $0.2 \mu \mathrm{m}$ syringe filter then injected into the Analyzer. Furthermore, ionization was performed using ESI electrospray ionization mode. The ESI parameters used include Column C-18 with a $1.8 \mu \mathrm{m} \times 2.1 \times 100 \mathrm{~mm}$ size, $0.2 \mathrm{~mL} / \mathrm{min}$ flow rate, and the acetonitrile mobile phase. The process also utilized a 1: $1 \mathrm{v} / \mathrm{v}$ water, source voltage range of 4 50 volts, and a capillary temperature of $50^{\circ} \mathrm{C}$. The molecular weight of peptides was analyzed by mass spectroscopy, while the de-convolution calculations were conducted using ESI-prot online (www.bioprocess.org/esiprot/) (Zhoum Guo, Shi, Jiang, \& Wang 2016).

\section{RESULTS AND DISCUSSION \\ Proximate content of Soy Protein Isolates}

Table 2 shows the proximate data of soy protein isolates, indicating the presence of crude protein, crude fat, moisture, and ash contents. The proximate analysis results show a crude protein content of $<50 \%$. This low level was probably due to the lack of an optimal isolation process for soy protein, and most were assumed to be soluble and not precipitated. This study was performed using an imported variant with a possible difference in chemical composition from the local form. Furthermore, results from the moisture analysis and ash contents indicated a relatively low moisture range for the isolates. The highest value tends to make the microbes grow easier and trigger legume damage with mold. However, total ash content determination was conducted to establish the quality of soybean processing. This parameter represents the presence of important minerals, including organic and inorganic salts where a high amount consequently influenced the enzyme activity in food production.

\section{Hydrolysis of Soy Protein Isolates}

The hydrolysis of soy protein isolates was performed using the $0.2 \%(\mathrm{w} / \mathrm{v})$ papain enzyme with incubation temperatures of 37,50 , and $55{ }^{\circ} \mathrm{C}$ 
(Mutamimah et al., 2018). Figure 1 shows the data of the percentage of protein hydrolyzed based on the degree of hydrolysis (\% DH).

The results showed the highest \% $\mathrm{DH}$ values obtained at $50{ }^{\circ} \mathrm{C}$, with an incubation time of 3 hours. However, the most significant $\% \mathrm{DH}$ value at $37{ }^{\circ} \mathrm{C}$ was observed at 6 hours, while $55^{\circ} \mathrm{C}$ obtained at 2 hours. The differences in \% $\mathrm{DH}$ value at various conditions were attributed to the effect of enzyme activity. However, this optimum enzyme activity was achieved at $50^{\circ} \mathrm{C}$. In addition, the hydrolysis degrees value reported at $37^{\circ} \mathrm{C}$ increased linearly over 1-6 hours, while a steady decline was observed with exposure to $50{ }^{\circ} \mathrm{C}$ and $55^{\circ} \mathrm{C}$, which was prominent after 3 and 2 hours. This phenomenon occurs due to the tendency for higher hydrolysis temperature probably increasing the kinetic energy of enzymes and substrate. Therefore, the molecular collisions tend to become faster and the enzyme-substrate complex formed produces ideal activation energy for the inception of a reaction. This condition leads to better effectiveness, and consequently higher product yield at the optimum temperature (Schowen, 2003)

In contrast with a study by Anggraini \& Yunianta, (2015) the highest hydrolysis degree value of $35.39 \%$ was produced using the papain enzyme at $50{ }^{\circ} \mathrm{C}$. This was stipulated as the temperature for optimal activity (Ashie, Sorensen, \& Nielsen, 2002). However, the highly significant hydrolysis degree was associated with the amount of product and was estimated to have a directly proportional relationship with the amount of dissolved protein or free amino groups (Sun, 2011). Marcela, (2017) ascribed the elevated values to an increase in peptides and amino acids dissolved in TCA, following the incidence of peptide bond breakage during protein hydrolysis. The extent of degradation recorded in this study is indicated by the effect of enzyme concentration and the time required. Therefore, the most efficient papain concentration involved in the hydrolysis of soy milk protein was $0.2 \%$, over a 3 hours process duration.

\section{Soy Protein Hydrolysate Profile Results of SDS-PAGE Analysis}

The SDS-PAGE analysis of soy protein hydrolysate was conducted to assess the protein profile before and after hydrolysis. Figure 2 shows the analysis results obtained at optimum temperature $\left(50{ }^{\circ} \mathrm{C}\right)$. Figure 2 demonstrates the different sizes / molecular weights of protein bands in the soy protein profile before and after hydrolysis. In addition, several major bands appeared below $39.5 \mathrm{KDa}$ at 0 hours and were assumed to be the glycinin type (Wang, Qin, Sun, \& Zhao, 2014). Moreover, other protein varieties were observed above $78 \mathrm{kDa}$, therefore indicating the presence of $\beta$-conglycinin forms (Barać, Pešić, Žilić, \& Srebrić, 2011). These bands detected tend to decrease in intensity and fades away after hydrolysis at 1-4 hours, followed by an increase in thickness to below $10 \mathrm{KDA}$ over time. Furthermore, this outcome indicates the complete breakdown of glycinin and $\beta$-conglycinin present in soy protein isolates. However, the bands subsequently reappeared with lower intensity at 5-6 hours. This finding is in line with the results obtained during hydrolysis degree evaluation at $50{ }^{\circ} \mathrm{C}$, where another decline in $\mathrm{DH}$ value was recorded 5-6 hours after the optimum condition was reached at 3 hours. Based on the soy protein isolate profile, an extended hydrolysis time using papain enzyme leads to more significant conversions of longer protein structures into shorter peptides.

The soybean protein is known to have a $\beta$ conglycinin fraction, consisting of $\alpha \beta$-conglycinin, $\beta$ $\beta$-conglycinin, and $\gamma \beta$-conglycinin. These components possess molecular weights of 80.22, 48.42 , and $46.24 \mathrm{kDa}$, respectively. Particularly, the single protein fraction termed glycinin is characterized by A-glycinin and B-glycinin, with molecular weights of $34-35$ and 18-22 KDa, respectively (Barać et al., 2011). This glycinin molecule model is a hexamer comprising of five subunits, including Gly I (A1A B1B), Gly II (A2 B1B), Gly III (A1B B2), Gly IV (A4 B5 B3), and Gly V (A3 B4), where each has two polypeptide components, encompassing acid and base. Meanwhile, $\beta$ conglycinin is a glycoprotein present in soybean with a trimeric molecular model and is known to possess 3 subunit types, including the $\alpha, \alpha$, and $\beta$ (Wang et al., 2014).

\section{HMG-CoA Reductase Soy Protein Hydrolysate Inhibitory Activity}

Figure 3 shows the results of the HMG-CoA reductase inhibitory activity test for soybean hydrolysates. The results showed the highest inhibition activity obtained at $50{ }^{\circ} \mathrm{C}(95.65 \%)$, with a concentration of $39.21 \mu \mathrm{g} / \mathrm{mL}$. This was followed by treatments at $37{ }^{\circ} \mathrm{C}(78.29 \%$ with concentration of $83.78 \mu \mathrm{g} / \mathrm{mL})$, and $55 \quad{ }^{\circ} \mathrm{C} \quad(52.37 \%$ with concentration of $30.15 \mu \mathrm{g} / \mathrm{mL}$ ).

The difference in HMG-CoA reductase inhibition was probably due to the relative difference of the number of peptide fragments produced in each hydrolysate. These phenomena can be seen from the results of the different electrophoretic band separations from each sample (Figure 2). According to Pak et al., (2005) soybeans hydrolysis using pepsin as a protease enzyme can produce anti-cholesterol activity, with a $45 \%$ inhibition value (concentration of protein $1 \mathrm{ppm})$.

Moreover, HMG-CoA reductase is a controlling enzyme in cholesterol biosynthesis (EC 1.1.1.88; NADPH dependent, EC 1.1.1.34) produced from the mevalonate pathway. The introduction of catalysts of this reaction facilitates the conversion of HMG-CoA to mevalonic acid and is considered the first step in cholesterol biosynthesis (Figure 4). 


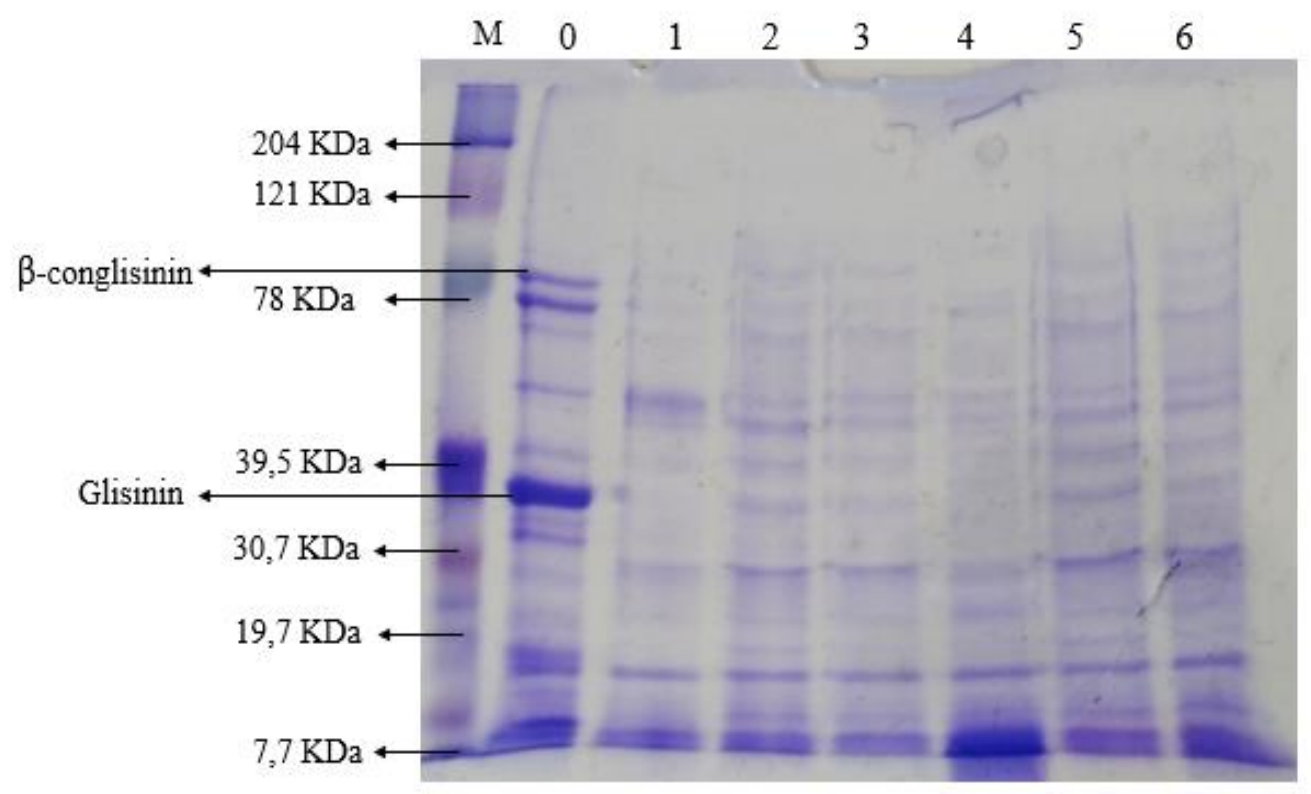

Figure 2. Soy protein hydrolysate electrophoregram $(M=$ Marker, $0=$ before hydrolysis, $1-6=$ hydrolysis time $1-6$ hours)

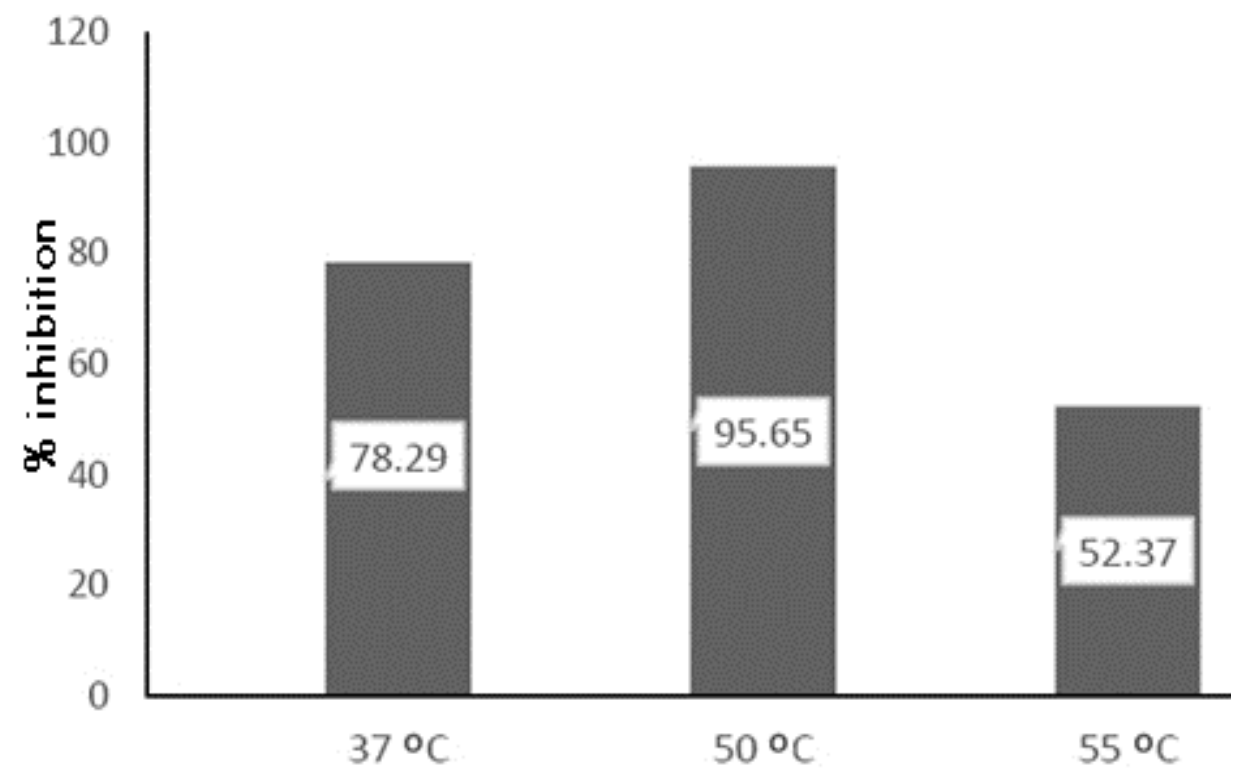

Figure 3. Percent inhibition of HMG-CoA reductase from soy hydrolysate

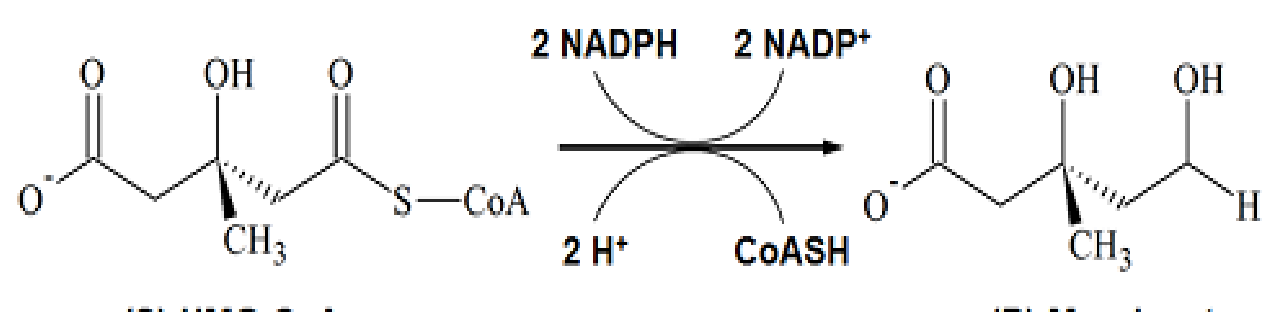

(S)-HMG-COA

(R)-Mevalonate

Figure 4. The formation reaction of mevalonic acid from HMG-CoA using HMG-CoA reductase enzyme and 2 molecules of NADPH through the transfer of 2 hydride ions. (Son et al., 2013) 
The HMG-CoA reductase enzyme functions by catalyzing the HMG-CoA compounds into mevalonic acid, with the help of NADPH, estimated to serve as a precursor in cholesterol formation. Meanwhile, the inhibitors of this enzyme tend to effectively reduce cholesterol biosynthesis and are considered valuable hypolipidemic agents, therefore the drug of choice for atherosclerosis. In addition, pravastatin is a polyketide bioactive component synthesized by the microorganism Bacillus megaterium and is commercially used as one of the drugs to reduce cholesterol biosynthesis. The medication activity is executed by inhibiting the HMG-CoA reductase enzyme, due to the structural characteristics with close resemblance to HMG-CoA. However, the enzyme inhibition in the liver instigates an increase in hepatic LDL (low-density lipoprotein) receptor expression, which reduces plasma LDL cholesterol levels. Therefore, a large number of HMG-CoA reductase inhibitor studies use pravastatin as positive control while treating hypercholesterolemic disorders (McFarland et al., 2014).

\section{Results of Soy Protein Hydrolysate Separation and} Molecular Weight Analysis

The soy protein hydrolysate with the highest HMG-CoA reductase inhibitory capacity was purified and separated by gel filtration chromatography (Sephadex G-10). Figure 5 shows the fractionation result, and the 21 st fraction reportedly produced the most significant absorption value, with an absorbance of 0.36 . This yield is assumed to contain protein/peptide with a smaller molecular weight compared to others. In addition, further analysis was performed for molecular weight using the LCMS QTOF Mass Analyzer, and the results are shown in Figure 6.

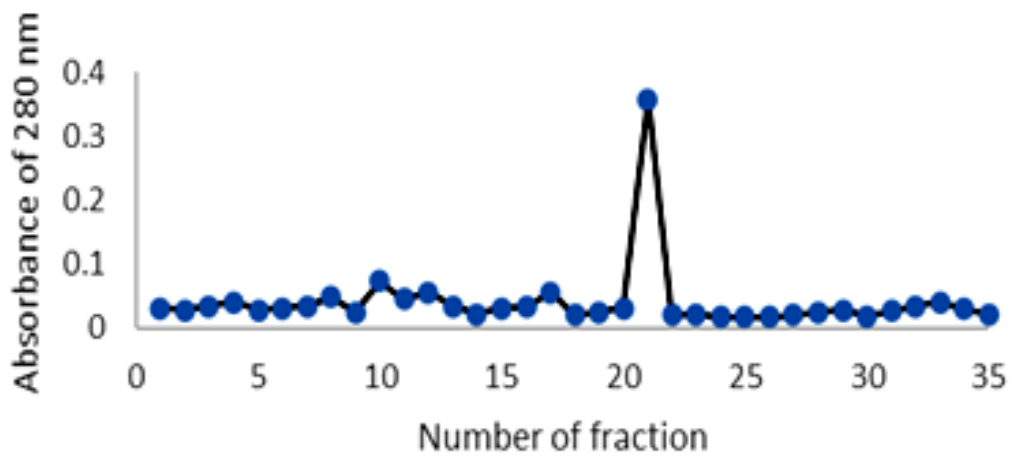

Figure 5. Fractionation results of soy protein hydrolysate $\left(50^{\circ} \mathrm{C}\right)$

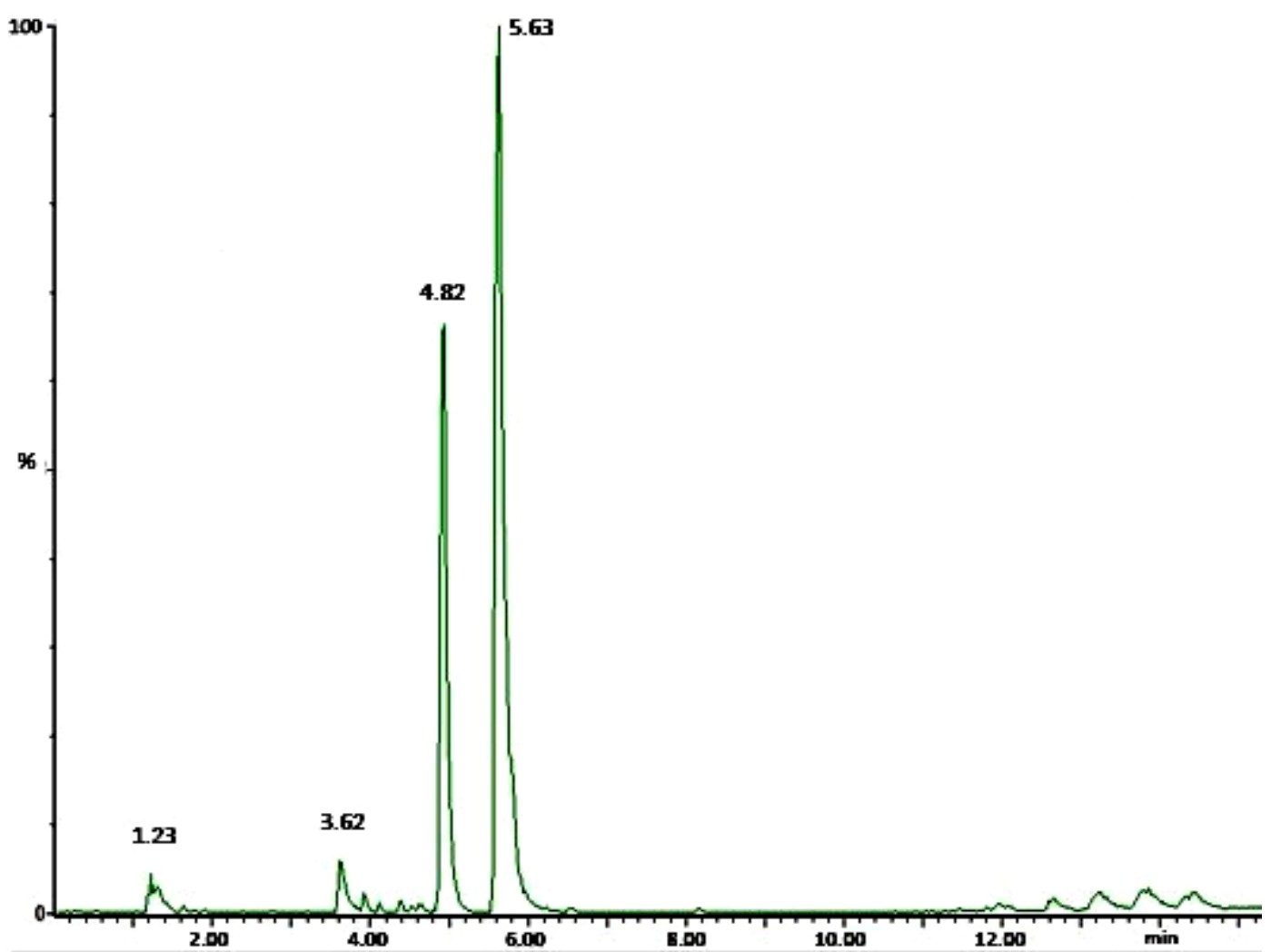

Figure 6. Chromatogram for the 21 st fraction of LCMS QTOF-MS analysis results. 


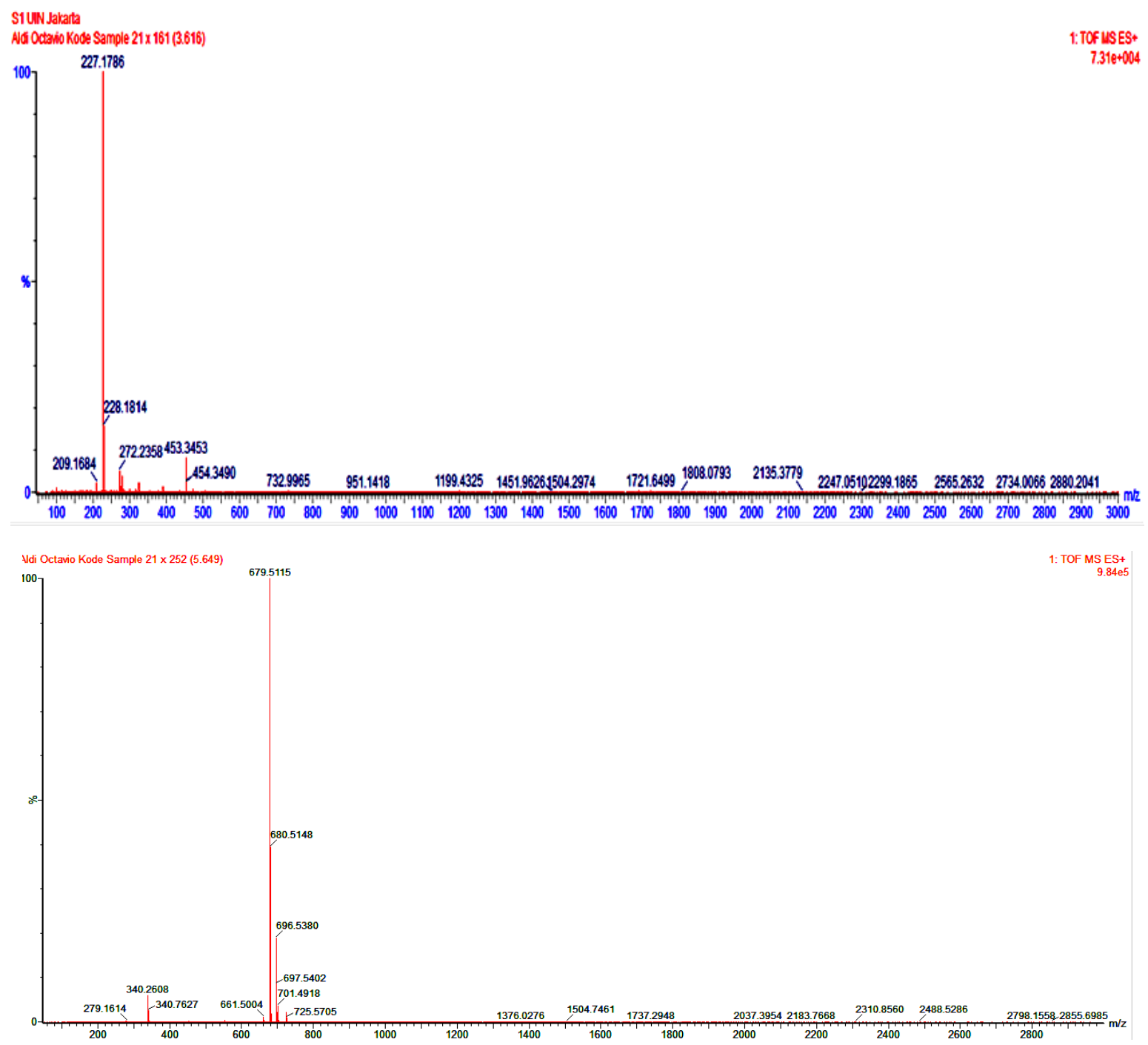

Figure 7. Mass spectrum of peptide compound fraction 21 with (a) tR 4.82 minutes (b) tR 5.53 minutes.

Figure 6 showed the LCMS analysis results of the 21 st fraction, and two dominant peaks with retention times of 4.82 and 5.53 minutes were obtained. Figure 7 demonstrated mass spectra with $\mathrm{m} / \mathrm{z}$ data, while the molecular weight was analyzed using ESIprot online (www.bioprocess.org/esiprot/). Based on the deconvolution results using ESlprot online (www.bioprocess.org/esiprot/), the molecular weights of the peptide compounds were $<3 \mathrm{kDa}$, at 1514 and $2029 \mathrm{Da}$, respectively. According to Lammi et al., (2015) a research by soybean hydrolysis using pepsin and trypsin enzymes produces peptides weighing $1178 \mathrm{Da}$ and $1177 \mathrm{Da}$, correspondingly. Therefore, both yields were considered to be of similar mass. Hence, there is a tendency for identical inhibitory potentials against HMG-CoA reductase enzyme activity. Many soy peptides have been identified to lower cholesterol and triglycerides, and to suppress fat synthesis and storage in different experimental systems. LPYPR from the glycinin subunit of the soybean was one of the initial hypocholesterolemic peptides discovered by Yoshikawa et al., (2000). Two other cholesterol- lowering peptides derived from glycinin are IAVPGEVA and IAVPTGVA (Pak, Koo, Lee, Kim, \& Kwon, 2005). Similar to LPYP, these peptides were shown to inhibit HMGR activity in cultured HepG2 cells and promote LDL uptake via the LDLR-SREBP2 pathway (Pak, Valeriy, Koo, Kwon, \& Yun, 2012). Lammi et al., (2015) uncovered two hypocholesterolemic peptides-YVVNPDNDEN and YVVNPDNNE derived from soy conglycinin, which also modulate cholesterol by an identical mechanism. However, further studies still needed to determine the peptide structure is required to ascertain this assertion.

\section{CONCLUSIONS}

The inhibitory activity of HMG-CoA reductase by soy protein hydrolysate from hydrolysis using papain enzyme has enormous potential as an anticholesterol agent. This product anticipated to serve as a replacement for statin drugs. Therefore, further in vivo testing and studies on peptide interactions with HMG-CoA enzyme is expected to influence future drug development. 


\section{ACKNOWLEDGEMENTS}

The authors are grateful to the Head of Integrated Laboratory Center, Syarif Hidayatullah State Islamic University, Jakarta and the Head of Central Laboratory for Pharmaceutical and Medical Technology, Institute for the Assessment and Application of Technology (BPPT) Serpong for facilitating this research activity from sample precipitation to anti-cholesterol activity testing.

\section{REFERENCES}

Agyei, D. (2015). Bioactive proteins and peptides from soybeans. Recent patents on food, Nutrition \& Agriculture, 7(2), 100-107. https://doi.org/10.2174/2212798407666150 629134141

Anderson, J. W., \& Hoie, L. H. (2005). Weight loss and lipid changes with low-energy diets: comparator study of milk-based versus soybased liquid meal replacement interventions. Journal of the American College of Nutrition, 24(3), 210-216. https://doi.org/10.1080/07315724.2005.107 19467

Anggraini, A., \& Yunianta. (2015). Pengaruh suhu dan lama hidrolisis enzim papain terhadap sifat kimia, fisik dan organoleptik sari edamame. Jurnal Pangan Dan Agroindustri, 3(3), 1015-1025.

AOAC International. (2016). Official Methods of Analysis of AOAC IInternational. Aoac, February, 3172.

Ashie, I. N. A., Sorensen, T. L., \& Nielsen, P. M. (2002). Effects of papain and a microbial enzyme on meat proteins and beef tenderness. Journal of Food Science, 67(6), 2138-2142. https://doi.org/10.1111/i.13652621.2002.tb09516.x

Barać, M., Pešić, M., Žilić, S., \& Srebrić, M. (2011). Identification of soluble protein fractions and their subunits in soybeans with black and yellow kernel coat. Agriculture, September 2015, 681-685.

Cho, S.-J., Juillerat, M., \& Lee, C.-H. (2008). Cholesterol lowering mechanism of soybean protein hydrolysate. Journal of Agricultural and Food Chemistry, 55, 10599-10604. https://doi.org/10.1021/jf071903f

Csonka, C., Sárközy, M., Pipicz, M., Dux, L., \& Csont, T. (2016). Modulation of hypercholesterolemia-induced oxidative/ nitrative stress in the heart. Oxidative Medicine and Cellular Longevity, 2016. https://doi.org/10.1155/2016/3863726

He, R., Cai, P., Wu, G., Zhang, C., Zhang, D., \& Chen, S. (2015). A rapid and sensitive method for the quantitation of microgram quantities of protein utilizing the principle of protein-dye binding. World Journal of Microbiology \&
Biotechnology, $\quad 31(11), \quad 248-254$. https://doi.org/10.2323/igam.2.195

Hippisley-Cox, J., \& Coupland, C. (2010). Unintended effects of statins in men and women in England and Wales: Population based cohort study using the QResearch database. BMJ (Online), 340(7758), 1232. https://doi.org/10.1136/bmi.c2197

Hoie, L. H. (2010). Cholesterol lowering effects of soy protein and how denatured protein may increase the risk for cardiovascular disease (Issue June). Nama jurnal? volume(no) halaman????

Hoyle, N. T., \& Merrltt, J. H. (1994). Quality of fish protein hydrolysates from herring (Clupea harengus). Journal of Food Science, 59(1), 76$79 . \quad$ https://doi.org/10.1111/j.13652621.1994.tb06901.x

Huupponen, R., \& Viikari, J. (2013). Statins and the risk of developing diabetes. BMJ (Online), 346(7911), $1-2$. https://doi.org/10.1136/bmi.f3156

Laemmli, U. K. (1970). Cleavage of structural proteins during the assembly of the head of bacteriophage T4. Nature, 227(5259), 680685.

Lammi, C., Zanoni, C., \& Arnoldi, A. (2015). IAVPGEVA, IAVPTGVA, and LPYP, three peptides from soy glycinin, modulate cholesterol metabolism in HepG2 cells through the activation of the LDLR-SREBP2 pathway. Journal of Functional Foods, 14, 469-478. https://doi.org/https://doi.org/10.1016/i.jff.2 015.02 .021

Li, C. H., Li, M., Chang, W. R., \& Guo, B. J. (2008). Purification and characterization of a novel cholesterol-lowering protein from the seeds of Senna obtusifolia. Science in China, Series C: Life Sciences, 51(11), 1020-1024. https://doi.org/10.1007/s1 1427-008-0129-2

Liang, G., Kou, H., Wang, T. T., Guo, Y., Ping, J., \& Wang, H. (2015). Optimization, validation and application of spectrophotometric assay for 3hydroxy-3-methylglutarylcoenzyme a reductase activity. Tropical Journal of Pharmaceutical Research, 14(4), 671-677. https://doi.org/10.4314/tipr.v14i4.16

Lyons, K. S., \& Harbinson, M. (2009). Statins: In the beginning. Journal of the Royal College of Physicians of Edinburgh, 39(4), 362-364. https://doi.org/10.4997/JRCPE.2009.425

Marcela, G.-M. (2017). Bioactive peptides from legumes as anticancer therapeutic agents. International Journal of Cancer and Clinical Research, 4(2), 1-10. https://doi.org/ 10.23937/2378-3419/1410081

McFarland, A. J., Anoopkumar-Dukie, S., Arora, D. S., Grant, G. D., McDermott, C. M., Perkins, A. V., \& Davey, A. K. (2014). Molecular 
mechanisms underlying the effects of statins in the central nervous system. International Journal of Molecular Sciences, 15(11), 2060720637. https://doi.org/10.3390/ijms 151120607

Murphy, C., Deplazes, E., Cranfield, C. G., \& Garcia, A. (2020). The role of structure and biophysical properties in the pleiotropic effects of statins. International Journal of Molecular Sciences, $21(22)$, 1-29. https://doi.org/10.3390/iims21228745

Mutamimah, D., Ibrahim, B., \& Trilaksani, W. (2018). Antioxidant activity of protein hydrolysate produced from tuna eye (Thunnus sp.) by enzymatic hydrolysis. Jurnal Pengolahan Hasil Perikanan Indonesia, 21(3), 522-531. https://doi.org/10.17844/iphpi.v2 1i3.24736

Otvos, J. D., Collins, D., Freedman, D. S., Shalaurova, I., Schaefer, E. J., McNamara, J. R., Bloomfield, H. E., \& Robins, S. J. (2006). Low-density lipoprotein and high-density lipoprotein particle subclasses predict coronary events and are favorably changed by gemfibrozil therapy in the veterans affairs high-density lipoprotein intervention trial. Circulation, 113(12), 1556-1563. https://doi.org/10.1161/CIRCULATIONAHA. 1 05.565135

Pak, Valeriy V., Koo, M., Kwon, D. Y., \& Yun, L. (2012). Design of a highly potent inhibitory peptide acting as a competitive inhibitor of HMG-CoA reductase. Amino Acids, 43(5), 2015-2025. https://doi.org/10.1007/s00726-012-1276-0

Pak, V V, Koo, M., Lee, N., Kim, M. S., \& Kwon, D. Y. (2005). Ile - Ala - Val - Pro and its derivatives revealed using the semiempirical AM1 method $41(4), 367-372$.

Pak, V V, Koo, M. S., Kasymova, T. D., \& Kwon, D. Y. (2005). Isolation and identification of peptides from soy 11S-globulin with hypocholesterolemic activity. Chemistry of Natural Compounds, 41(6), 710-714. https://doi.org/10.1007/s10600-006-0017-6

Ramdath, D. D., Padhi, E. M. T., Sarfaraz, S., Renwick, S., \& Duncan, A. M. (2017). Beyond the cholesterol-lowering effect of soy protein: A review of the effects of dietary soy and its constituents on risk factors for cardiovascular disease. Nutrients, 9(4), 324. https://doi.org/10.3390/nu9040324

Rinto, Lestari, S. D., Putri, A., \& Waktu, T. (2019). antioxidant and anticholesterol activity of rusip extract. JPB Kelautan dan Perikanan, 14(1), 18. https://doi.org/10.15578/ipbkp.v14i1.568

Scalbert, A., Johnson, I. T., \& Saltmarsh, M. (2005). Polyphenols: antioxidants and beyond. The American Journal of Clinical Nutrition, 81(1), 215S-217S. https://doi.org/10.1093/ajcn/81.

\section{$1.215 S$}

Schowen, R. L. (2003). How an enzyme surmounts the activation energy barrier. Proceedings of the National Academy of Sciences of the United States of America, 100(21), 1193111932.

https://doi.org/10.1073/pnas.2235806100

Shimakage, A., Shinbo, M., \& Yamada, S. (2012). ACE inhibitory substances derived from soy foods. Journal of Biological Macromolecules, 12(3), 72-80.

Son, M., Baek, A., Sakkiah, S., Park, C., John, S., \& Lee, K. W. (2013). Exploration of virtual candidates for human HMG-CoA reductase inhibitors using pharmacophore modeling and molecular dynamics simulations. PLOS ONE, 8(12). https://doi.org/10.1371/journal.pone. 0083496

Sun, X. D. (2011). Enzymatic hydrolysis of soy proteins and the hydrolysates utilisation. International Journal of Food Science \& Technology, 46(12), 2447-2459. https://doi.org/10.1111/i.1365.2621.2011.0 2785.x

Trialists, C. T. (2005). Efficacy and safety of cholesterol-lowering treatment: Prospective meta-analysis of data from $90 \quad 056$ participants in 14 randomised trials of statins. Lancet, 366(9493), 1267-1278. https://doi.org/10.1016/S0140-6736(05) 67394-1

Vasconcellos, F. C. S., Woiciechowski, A. L., Soccol, V. T., Mantovani, D., \& Soccol, C. R. (2014). Antimicrobial and antioxidant properties of conglycinin and glycinin from soy protein isolate. Int.J.Curr.Microbiol.App.Sci, 3(8), 144157.

Virani, S. S., Alonso, A., Benjamin, E. J., Bittencourt, M. S., Callaway, C. W., Carson, A. P., Chamberlain, A. M., Chang, A. R., Cheng, S., Delling, F. N., Diousse, L., Elkind, M. S. V., Ferguson, J. F., Fornage, M., Khan, S. S., Kissela, B. M., Knutson, K. L., Kwan, T. W., Lackland, D. T., ... Heard, D. G. (2020). Heart disease and stroke statistics 2020 update: A report from the American Heart Association. In Circulation.https://doi.org/10.1161/CIR.000000 0000000757

Wang, T., Qin, G.-X., Sun, Z.-W., \& Zhao, Y. (2014). Advances of research on glycinin and $\beta$ conglycinin: A review of two major soybean allergenic proteins. Critical Reviews in Food Science and Nutrition, 54(7), 850-862. https://doi.org/10.1080/10408398.2011.613 534

Yoshikawa, M., Fujita, H., Matoba, N., Takenaka, Y., Yamamoto, T., Yamauchi, R., Tsuruki, H., \& Takahata, K. (2000). Bioactive peptides derived from food proteins preventing lifestyle- 
related diseases. BioFactors, 12(1-4), 143-146. https://doi.org/10.1002/biof.5520120122

Zhou, S., Guo, C., Shi, F., Jiang, W., \& Wang, L. (2016). Application of an ultrahighperformance liquid chromatography coupled to quadrupole-orbitrap high-resolution mass spectrometry for the rapid screening, identification and quantification of illegal adulterated glucocorticoids in herbal medicines. Journal of Chromatography $B$, 1038, 34-42. https://doi.org/https://doi.org/ 10.1016/i.jchromb.2016.10.010 